\title{
URGENSI AUTOPSI FORENSIK DAN IMPLIKASINYA DALAM TINDAK PIDANA PEMBUNUHAN
}

\author{
Samsudi \\ Fakultas Hukum Universitas Jember \\ email: samsudiborju.fh@unej.ac.id; \\ Y.A. Triana Ohoiwutun \\ Fakultas Hukum Universitas Jember \\ email: trianaohoiwutun@unej.ac.id \\ Godeliva Ayudyana Suyudi \\ Program Studi Magister Ilmu Hukum Fakultas Hukum Universitas Jember \\ email: godeliva98@gmail.com \\ Widowati \\ Fakultas Hukum Universitas Tulung Agung \\ email: widowati@unita.ac.id
}

disampaikan 25/08/2020 - di-review 14/10/2020 - diterima 16/11/2021

DOI: $10.25123 /$ vej.v7i2.4197

\begin{abstract}
The court does not always demand or require visum et repertum when examining homicide cases. Forensic autopsy may not be required at all by the criminal court when deciding that the accused is guilty of homicide as charged. The verdict may be reached based on other evidence. The author, using a juridical normative approach, concludes that the absence or presence of a visum et repertum does influence the judge' consideration and matters to the final verdict. Considering that, regardless of the surviving family's consent, in cases of unnatural death, forensic autopsy and the making of a visum et repertum should be mandatory.
\end{abstract}

Keywords:

forensic autopsy; visum et repertum; unnatural death

\begin{abstract}
Abstrak
Tidak dalam setiap kasus pembunuhan disyaratkan adanya autopsy forensic terhadap korban. Penelitian ini menelaah pembuktian pembunuhan yang dilakukan dengan atau tanpa vistum et repertum. Bahkan cukup dengan dukungan alat bukti cukup, hakim pidana dapat memutus terdakwa bersalah karena pembunuhan. Dengan pendekatan yuridis normatif ditemukan bahwa keberadaan atau ketiadaan visum et repertum berkorelasi dengan ratio decidendi hakim pemeriksa dan berpengaruh terhadap putusan akhir. Mengingat pentingnya visum et repertum dalam pembuktian penyebab kematian tidak wajar, direkomendasikan agar hal ini diwajibkan terlepas dari persetujuan keluarga korban.
\end{abstract}

Kata kunci: Autopsi forensik; visum et repertum; kematian tidak wajar 


\section{Pendahuluan}

Kasus kematian yang menghebohkan masyarakat terkait dugaan adanya pembunuhan sempat merebak beberapa waktu lalu. Kurun waktu yang tidak terlalu lama antara satu peristiwa dengan peristiwa lainnya, membuat fenomena mencari penyebab kematian seseorang menjadi hal yang menarik untuk dikaji. Misalnya, dalam kasus kematian Jamaluddin, hakim Pengadilan Negeri Medan, yang jenazahnya ditemukan di area kebun sawit Kabupaten Deliserdang 29 Nopember 2019; kemudian kasus kematian Lina Jubaedah mantan isteri komedian Sule yang wafat 4 Januari 2020 dan diautopsi beberapa hari kemudian setelah dimakamkan dikarenakan adanya dugaan kematian yang tidak wajar; dan kasus kematian Zefania Carina anak dari artis Karen Pooroe yang diduga jatuh dari lantai 6 apartemen 7 Februari 2020. Autopsi forensik dalam kasus kematian yang diduga tidak wajar memang menarik untuk dibahas, apalagi dalam kasuskasus tertentu tidak dilakukan autopsi forensik atau bedah mayat forensik, meskipun ada dugaan pembunuhan atau kematian tidak wajar.

Beberapa faktor tidak dilakukannya autopsi forensik, sepertinya dipandang hal yang "wajar dan biasa" di Indonesia; meskipun peristiwa hukum tersebut sampai bermuara di pengadilan. Dalam beberapa kasus implikasi dari tidak dilakukannya autopsi forensik memang tidak menjadikan terdakwanya bebas, apabila perbuatan terdakwa terbukti di persidangan dan hakim yakin bahwa terdakwalah yang bersalah.

Eksistensi autopsi forensik dalam setiap kasus kematian memang penting untuk dipahami oleh praktisi hukum, akademisi, pemerhati hukum maupun masyarakat pada umumnya; oleh karena itu, tulisan ini mencoba mengkaji putusan pengadilan yang telah berkekuatan hukum tetap terkait kasus kematian, baik pada kasus kematian yang diautopsi maupun tidak diautopsi. Putusan Pengadilan Negeri (selanjutnya disebut PN) Simalungun No. 304/Pid.B/2016/PN Sim tanggal 21 September 2016 merupakan putusan yang dipilih untuk tindak pidana pembunuhan yang korbannya diautopsi; sedangkan Putusan PN Poso No. 2/Pid.B/2018/PN Pso tanggal 8 Maret 2018 merupakan kasus pembunuhan yang korbannya tidak diautopsi. Dari kedua kasus tersebut diharapkan semakin 
memperjelas urgensi autopsi forensik dalam setiap peristiwa pembunuhan atau setiap kematian yang diduga tidak wajar.

Kebenaran materiil merupakan kebenaran yang dituju di dalam setiap pemeriksaan perkara pidana dan pemberdayaan disiplin ilmu lain di luar hukum pidana memang tidak dapat dihindarkan. Tujuan penemuan kebenaran materiil di dalam setiap pemeriksaan perkara pidana inilah yang menjadikan hukum pidana berkoneksi, berinteraksi dan berdependensi dengan disiplin ilmu lain di luar hukum pidana atau disebut ilmu forensik. Forensik adalah suatu ilmu pengetahuan yang menggunakan multidisiplin ilmu, dengan menerapkan ilmu pengetahuan alam seperti kimia, fisika, biologi, psikologi, kedokteran dan kriminologi yang bertujuan membuat terang suatu perkara pidana dan membuktikan ada tidaknya kejahatan atau pelanggaran dengan memeriksa barang bukti fisik dalam perkara tersebut. ${ }^{1}$ Psikiatri forensik, psikologi forensik, kedokteran forensik, digital forensik, anthropologi forensik, toxicology forensik, odontology forensik dan sebagainya, adalah disiplin ilmu lain (di luar hukum) yang diperbantukan dalam penegakan hukum untuk penemuan kebenaran materiil.

Kamus Besar Bahasa Indonesia mengartikan autopsi sebagai pemeriksaan tubuh mayat dengan jalan pembedahan untuk mengetahui penyebab kematian, penyakit, dan sebagainya; bedah mayat. ${ }^{2}$ Menurut Gobel, autopsi berasal dari bahasa Yunani autopsia yang berarti "melihat dengan mata sendiri", yang lebih dikenal sebagai pemeriksaan post-mortem, yang dalam terminologi ilmu kedokteran berarti pemeriksaan terhadap mayat, baik untuk tujuan kepentingan ilmu kedokteran, maupun membantu dalam proses tindakan kriminal. ${ }^{3}$ Melalui autopsi forensik dalam kasus kematian pada hakikatnya untuk menuju pada penemuan kebenaran materiil sebagaimana tujuan dalam setiap pemeriksaan

\footnotetext{
M. Marwan dan Jimmy P, Kamus Hukum Dictionary of Law Complete Edition, Reality Publisher, Surabaya, 2009, hlm. 211-212.

2 Departemen Pendidikan Nasional, Kamus Besar Bahasa Indonesia Edisi Keempat, Gramedia Pustaka Utama, Jakarta, 2015, hlm. 102.

3 Putu Pradnyasanti Laksmi, IB Putu Alit, Henky, Deskripsi Faktor-Faktor Yang Memengaruhi Penolakan Otopsi Pada Kasus Kematian Yang Diduga Tidak Wajar, Jurnal Medika Udayana, Vol. 9, No. 7 2020, hlm. 86-87.
} 
perkara pidana; namun demikian, dalam implementasinya masih "jauh panggang dari api", karena tidak setiap kasus pembunuhan dilakukan autopsi forensik.

Alasan peniadaan autopsi forensik, dalam putusan pengadilan lazim disebutkan dalam keterangan visum et repertum, yaitu berdasarkan pemeriksaan luar terhadap tubuh korban. Pemeriksaan luar tubuh korban inilah yang menarik untuk dicermati, apalagi pembunuhan diformulasikan sebagai delik materiil dengan segala konsekuensi yuridisnya dalam pembuktian. Autopsi forensik merupakan fokus dalam penulisan ini, dengan permasalahan urgensi pemeriksaan autopsi forensik dalam kasus tindak pidana pembunuhan; serta konsekuensi yuridis hubungan antara autopsi forensik dengan tindak pidana pembunuhan di dalam pembuktian perkara.

Penulisan ini merupakan penelitian hukum normatif atau penelitian hukum doktrinal dengan fokus urgensi autopsi forensik, dengan menganalisis aturan atau norma hukum sebagai bahan hukum primer ${ }^{4}$ meliputi: Kitab Undang-undang Hukum Pidana (selanjutnya disebut KUHP), UU No. 8 Tahun 1981 tentang Kitab Undang-undang Hukum Acara Pidana (selanjutnya disebut KUHAP), Instruksi Kapolri No. Pol.: Ins/E/20/IX/75 tanggal 19 September 1975 tentang Tata Cara Permohonan/Pencabutan Visum et Repertum (selanjutnya disebut Instruksi Kapolri Tahun 1975). Bahan hukum primer lain berupa putusan pengadilan yang telah berkekuatan hukum tetap, yaitu Putusan No. 304/Pid.B/2016/PN Sim yang diputus PN Simalungun tanggal 21 September 2016 dan Putusan No. 2/Pid.B/2018/PN Pso yang diputus PN Poso tanggal 8 Maret 2018.

Fokus penulisan mengenai eksistensi autopsi forensik yang berorientasi pada implikasinya dalam tindak pidana pembunuhan menggunakan analisis deskriptif kualitatif. Analisis dilakukan dengan cara menjelaskan mengenai urgensi autopsi forensik dalam kasus tindak pidana pembunuhan. Sebagai delik materiil, tindak pidana pembunuhan mensyaratkan adanya hubungan kausal antara sebab perbuatan dengan akibat yang dilarang undang-undang, dan

4 Lihat Peter Mahmud Marzuki, Penelitian Hukum Normatif, Kencana, Jakarta, 2011, hlm. 182. Bahan hukum primer merupakan bahan hukum yang mempunyai sifat autoritatif, yaitu memiliki otoritas tertentu. 
penulisan ini secara deskriptif kualitatif menganalisis urgensi autopsi forensik dengan segala konsekuensi yuridisnya. Dengan penulisan ini diharapkan dapat menambah referensi dan wawasan mengenai urgensi autopsi forensik dalam kasus-kasus pembunuhan.

\section{Pembahasan}

\section{Urgensi Pemeriksaan Autopsi Forensik dalam Kasus Tindak Pidana Pembunuhan}

Ilmu kedokteran adalah induk dari ilmu kedokteran forensik yang diaplikasikan dalam penegakan hukum, baik dalam perkara pidana maupun perkara lain. Ilmu kedokteran forensik atau ilmu kedokteran kehakiman merupakan ilmu kedokteran yang penerapannya dalam rangka penegakan hukum (medicine for law),5 yang mekanisme dan prosedur penatalaksanaannya berdasarkan peraturan hukum yang berlaku. Dalam prosedur mediko legal penatalaksanaannya dan berbagai aspek yang berkaitan pelayanan kedokteran dilakukan untuk kepentingan hukum, ${ }^{6}$ dan untuk kepentingan penegakan hukum itulah ada titik temu dependensi hukum yang berbasis pada hasil pemeriksaan kedokteran forensik.

Keberadaan pemeriksaan kedokteran forensik atas mayat yang diduga korban tindak pidana ditentukan di dalam KUHAP Pasal 133 khususnya ayat (1), bahwa:

"dalam hal penyidik untuk kepentingan peradilan menangani seorang korban, baik luka, keracunan ataupun mati yang diduga karena peristiwa yang merupakan tindak pidana, ia berwenang mengajukan permintaan keterangan ahli kepada ahli kedokteran kehakiman atau dokter dan atau ahli lainnya".

Merujuk pada KUHAP Pasal 133 ayat (1), posisi penyidik sangatlah penting dalam menangani "barang bukti" berupa tubuh manusia, khususnya dalam rangka pembuktian perkara yang bermuara pada tujuan penemuan kebenaran materiil.

5 Y.A. Triana Ohoiwutun, Ilmu kedokteran Forensik, Interaksi dan Dependensi Hukum pada Ilmu Kedokteran, Pohon Cahaya, Yogyakarta, 2016, hlm. 10.

6 Marhcel M. Maramis, Tinjauan Yuridis Terhadap Otopsi Medikolegal Dalam Pemeriksaan Mengenai Sebab-sebab Kematian, Jurnal Hukum Unsrat, Vol. 21, No. 5 2016, hlm. 88. 
Merujuk pada Pasal 133 ayat (1) KUHAP, adanya pemeriksaan mayat dan atau autopsi forensik berdasarkan pada permintaan penyidik yang dibuat secara tertulis. Surat permintaan penyidik berupa permohonan yang ditujukan pada sarana pelayanan kesehatan dalam pembuatan visum et repertum, baik untuk korban tindak pidana dalam keadaan hidup maupun mati. Instansi kepolisian yang bertanggung jawab dalam penyidikan perkara tindak pidana kejahatan terhadap nyawa atau tubuh, secara administrasi bertanggungjawab penuh dalam proses pembuatan visum et repertum.

Dalam kasus kejahatan terhadap nyawa atau tubuh, posisi visum et repertum sebagai pengganti "barang bukti" tubuh manusia, berperan penting dalam menerangkan atau menjelaskan kondisi luka atau kondisi mayat pada saat dilakukannnya pemeriksaan kedokteran forensik. Dalam visum et repertum lebih lanjut disimpulkan mengenai hubungan kausal antara kondisi perlukaan yang berakibat pada kualifikasi luka tertentu atau kematian seseorang.

Sementara itu, dalam kasus kematian yang diduga ada peristiwa pidana, KUHAP Pasal 134 ayat (1) menentukan, bahwa dalam hal sangat diperlukan di mana untuk keperluan pembuktian bedah mayat tidak mungkin lagi dihindari, penyidik wajib memberitahukan terlebih dahulu kepada keluarga korban; ayat (2) dalam hal keluarga keberatan, penyidik wajib menerangkan dengan sejelasjelasnya tentang maksud dan tujuan perlu dilakukannya pembedahan tersebut. Merujuk pada KUHAP Pasal 134, menempatkan posisi strategis penyidik sebagai aparat yang bertugas dan bertanggung jawab dalam pelaksanaan autopsi forensik.

Instruksi Kapolri Tahun 1975 merupakan salah satu landasan hukum pelaksanaan pembuatan visum et repertum. Instruksi Kapolri Tahun 1975 angka 3 secara tegas menyebutkan "sama sekali tidak dibenarkan permintaan visum et repertum atas mayat berdasarkan pemeriksaan luar saja". Bertolak dari Instruksi Kapolri Tahun 1975, penyidik melalui surat permintaan visum et repertum yang ditujukan pada sarana pelayanan kesehatan, seharusnya meminta pelaksanaan autopsi forensik dalam setiap pemeriksaan atas mayat dalam peristiwa pidana.

Dalam menangani kasus kematian yang diduga karena peristiwa pidana, dalam implementasinya terkendala dengan adanya keberatan dari pihak keluarga 
korban untuk dilakukannya autopsi forensik. Dalam Putusan No. 2/Pid.B/2018/PN Pso disebutkan bahwa "tidak dilakukan pemeriksaan dalam atau autopsi secara menyeluruh, sebab keluarga tidak menginginkan adanya autopsi mayat secara menyeluruh". Merujuk pada Putusan No. 2/Pid.B/2018/PN Pso, adanya persetujuan keluarga turut menentukan terlaksananya tindakan autopsi forensik.

Hal adanya persetujuan keluarga dalam pelaksanaan autopsi forensik juga dapat diindikasikan dari beberapa kasus kematian yang menarik perhatian masyarakat, seperti kematian Jamaluddin, Lina Jubaedah, dan Zefania Carina, yang mana autopsi forensik dilakukan setelah adanya permintaan dari pihak keluarga atau karena penyidik memandang perlu untuk dilakukannya autopsi forensik. Memang, KUHAP memposisikan peran strategis penyidik untuk terselenggaranya autopsi forensik, sebagaimana diformulasikan di dalam Pasal 134 ayat (2), apabila ada keberatan dari pihak keluarga, maka penyidik wajib menerangkan dengan sejelas-jelasnya tentang pentingnya autopsi forensik.

Apabila merujuk pada formulasi KUHAP Pasal 134 ayat (2) menyiratkan dalam pelaksanaan autopsi forensik dengan seijin keluarga korban; padahal KUHP Pasal 222 menentukan bahwa:

"barangsiapa dengan sengaja mencegah, menghalang-halangi atau menggagalkan pemeriksaan mayat forensik, diancam dengan pidana penjara paling lama sembilan bulan atau pidana denda paling banyak empat ribu lima ratus rupiah".

Inkonsistensi antara formulasi KUHAP Pasal 134 ayat (2) dengan KUHP Pasal 222 tidak dikaji lebih lanjut dalam penelitian ini, karena hal ini memerlukan kajian tersendiri.

Autopsi forensik memang diperlukan dalam setiap pemeriksaan atas mayat, atau dapat dikatakan, bahwa pemeriksaan luar mayat tidak cukup untuk menentukan penyebab kematian seseorang. Pembatasan pemeriksaan luar mayat, dapat diibaratkan penyidik diminta untuk memeriksa jumlah uang dalam brankas, 
tetapi dilarang membukanya; ${ }^{7}$ dari aspek pemeriksa mayat dapat diibaratkan, dokter diminta menebak logam di dalam kotak kayu terkunci tanpa mengetahui isi sebenarnya logam tersebut, mungkin uang logam, logam baja, atau mungkin logam mulia. Hanya dengan membuka kotak kayu terkunci itulah, dapat diketahui secara pasti "misteri” isi logam di dalamnya.

Merujuk pada analogi paragraf tersebut di atas, dapat disimpulkan bahwa hanya dengan autopsi forensik atau melalui pembedahan mayatlah misteri kematian dapat diungkap dan diketemukan kepastian penyebabnya. Dari perspektif hukum pidana, tindak pidana pembunuhan diformulasikan sebagai delik materiil, yang konsekuensi yuridisnya, disyaratkan adanya hubungan kausal antara perbuatan terdakwa dengan akibat hilangnya nyawa orang lain. Korelasi antara perbuatan terdakwa dengan akibat hilangnya nyawa orang lain itulah yang seharusnya dapat dibuktikan dalam tindak pidana pembunuhan. Sebagaimana dikemukakan oleh Eddy O.S. Hiariej: ${ }^{8}$

"de leer van de causaliteit atau teori hubungan kausalitas teramat penting dalam menentukan pertanggungjawaban untuk delik-delik yang dirumuskan secara materiil, karena akibat yang ditimbulkan merupakan unsur delik".

Merujuk pada pendapat Hiariej, unsur akibat hilangnya nyawa orang lain yang disebabkan karena perbuatan terdakwalah yang dapat dijelaskan melalui pemeriksaan autopsi forensik. Adanya hubungan kausal antara penyebab perbuatan terdakwa dengan akibat hilangnya nyawa korban sebagai unsur delik, adalah parameter dalam menentukan pertanggungjawaban pidana, atau sebagai dasar menakar kesalahan terdakwa yang akan berkorelasi dengan penjatuhan sanksi. Autopsi forensik memang tidak dapat menentukan pelaku pembunuhan, namun dengan autopsi forensik dapat mengurai dan menjelaskan penyebab kematian.

7 Kastubi, Fungsi Bedah Mayat Forensik (Autopsi) Untuk Mencari Kebenaran Materiil Dalam Suatu Tindak Pidana, Jurnal Spektrum Hukum, Vol. 13, No. 1 2016, hlm. 73.

8 Eddy O.S. Hiariej, Prinsip-prinsip Hukum Pidana, Cahaya Atma Pustaka, Yogyakarta, 2016, hlm. 107. 
Menurut Wirjono Prodjodikoro, tidak ada suatu tindak pidana tanpa sifat melanggar hukum (wederrechtelijkheid, onrechtmatigeheid), ${ }^{9}$ dan berdasarkan fakta yang terungkap di persidangan, meskipun tanpa melalui pemeriksaan autopsi forensik, Putusan No. 2/Pid.B/2018/PN Pso yang memutus terdakwa K bin $\mathrm{R}$ terbukti secara sah dan meyakinkan bersalah melakukan tindak pidana pembunuhan. Putusan No. 2/Pid.B/2018/PN Pso, kemudian dikuatkan dengan Putusan Pengadilan Tinggi Sulawesi Tengah melalui Putusan No. 47/PID/2018/PT PAL tanggal 20 April 2018. Berdasarkan alat bukti keterangan saksi, keterangan ahli, surat dan keterangan terdakwa, Putusan No. 2/Pid.B/2018/PN Pso menunjukkan bahwa tidak ada tindak pidana tanpa sifat melanggar hukum (wederrechtelijkheid, onrechtmatigeheid), meskipun tanpa autopsi forensik.

Untuk menjelaskan urgensi autopsi forensik dalam tindak pidana pembunuhan, Putusan No. 2/Pid.B/2018/PN Pso dapat disandingkan dengan Putusan No. 304/Pid.B/2016/PN Sim. Penyebab pasti kematian seseorang dalam kesimpulan visum et repertum-lah yang dapat menentukan adanya hubungan kausal antara perbuatan terdakwa dengan akibat kematian korban sebagaimana diuraikan pada Tabel 1.

Tabel 1: Urgensi Autopsi Forensik dalam Tindak Pidana Pembunuhan

\begin{tabular}{|c|c|c|c|}
\hline No & Keterangan & $\begin{array}{l}\text { Putusan No. 304/Pid.B/2016/PN } \\
\text { Sim }\end{array}$ & $\begin{array}{l}\text { Putusan No. 2/Pid.B/2018/PN } \\
\text { Pso }\end{array}$ \\
\hline 1 & $\begin{array}{l}\text { Dakwaan } \\
\text { Penuntut Umum }\end{array}$ & $\begin{array}{l}\text { Primer: Pasal } 340 \text { KUHP jo Pasal } 55 \\
\text { ayat (1) Ke-1 KUHP; } \\
\text { Subsider: Pasal } 338 \text { Jo Pasal } 55 \text { ayat (1) } \\
\text { ke-1 KUHP. }\end{array}$ & $\begin{array}{l}\text { Primer: Pasal } 338 \text { KUHP; } \\
\text { Subsidair: Pasal } 353 \text { ayat (3) KUHP; } \\
\text { lebih subsider: Pasal } 351 \text { ayat (1) } \\
\text { KUHP. }\end{array}$ \\
\hline 2 & $\begin{array}{l}\text { Hasil } \\
\text { pemeriksaan } \\
\text { terhadap korban } \\
\text { berdasarkan } \\
\text { visum et } \\
\text { repertum }\end{array}$ & $\begin{array}{l}\text { Visum et Repertum No.: } \\
\text { 4939/IV/UPM/2016 tanggal } 09 \text { Mei } \\
\text { 2016: } \\
\text { Pemeriksaan Luar: } \\
\text { - Dijumpai lebam mayat yang tidak } \\
\quad \text { hilang pada penekanan; } \\
\text { - Dijumpai kaku mayat yang sudah } \\
\quad \text { sulit dilawan; } \\
\text { - Dijumpai luka memar dan luka lecet } \\
\quad \text { pada dagu; } \\
\text { - Dijumpai lidah tergigit; }\end{array}$ & $\begin{array}{l}\text { Visum et Repertum No.: } \\
\text { 445.1/275/UPTD.PKM-KLRG/2017 } \\
\text { tanggal 17 September 2017: } \\
\text { - telah dilakukan pemeriksaan luar } \\
\text { pada seorang laki-laki usia } 22 \\
\text { tahun, dari hasil pemeriksaan } \\
\text { didapatkan satu buah luka lecet di } \\
\text { bawah mata kanan yang diduga } \\
\text { diakibatkan oleh persentuhan } \\
\text { benda tumpul; } \\
\text { - didapatkan satu buah luka tusuk }\end{array}$ \\
\hline
\end{tabular}

9 Wirjono Prodjodikoro, Tindak-Tindak Pidana Tertentu di Indonesia, Refika Aditama, Bandung, 2012, hlm. 1. 


\begin{tabular}{|c|c|c|c|}
\hline & & $\begin{array}{l}\text { - Dijumpai luka lecet pada tangan; } \\
\text { - Dijumpai jejas jeratan dengan } \\
\text { resapan darah dan tanpa resapan } \\
\text { darah pada daerah leher; } \\
\text { - Dijumpai bintik-bintik perdarahan } \\
\text { pada kelopak mata bagian dalam; } \\
\text { - Dijumpai ujung-ujung jari tangan } \\
\text { dan kaki berwarna ungu. }\end{array}$ & $\begin{array}{l}\text { di belakang telinga kiri, satu buah } \\
\text { luka tusuk di punggung belakang } \\
\text { bagian bawah yang diduga } \\
\text { persentuhan benda tajam. Luka } \\
\text { tersebut menimbulkan halangan } \\
\text { dalam melakukan } \\
\text { kegiatan/pekerjaan sehari-hari } \\
\text { dan membutuhkan penanganan } \\
\text { medis lebih lanjut. }\end{array}$ \\
\hline & & $\begin{array}{l}\text { Pemeriksaan Dalam: } \\
\text { - Dijumpai lendir disertai buih-buih } \\
\text { halus pada saluran nafas; } \\
\text { - Dijumpai adanya sisa makanan } \\
\text { disertai aroma seperti bau tuak di } \\
\text { saluran makanan; } \\
\text { - Dijumpai pada pemotongan paru dan } \\
\text { hati keluar darah encer berwarna } \\
\text { merah kehitaman disertai buih-buih } \\
\text { halus yang sulit pecah; } \\
\text { - Dijumpai resapan darah dan daerah } \\
\text { pucat pada kulit dan otot leher; } \\
\text { - Dijumpai sisa makanan berupa nasi } \\
\text { di kantong lambung dengan } \\
\text { konsistensi lunak disertai aroma } \\
\text { seperti bau tuak. }\end{array}$ & $\begin{array}{l}\text { Visum et Repertum No. } \\
812 / 329.17 / \text { RM/RSMW/2017 } \\
\text { tanggal } 20 \text { September } 2020 \text { RSUD } \\
\text { Morowali dengan hasil pemeriksaan } \\
\text { atas mayat: } \\
\text { - pada tubuh korban terdapat luka } \\
\text { lecet ukuran } 3 \times 2 \mathrm{~cm} \text { di sudut } \\
\text { mata kanan; } \\
\text { - terdapat luka terjahit ukuran } \\
\text { panjang } 2 \mathrm{~cm} \text { setelah ditautkan, } \\
\text { disertai bekuan darah berwarna } \\
\text { merah kehitaman di sekitarnya. }\end{array}$ \\
\hline 3 & $\begin{array}{l}\text { Kesimpulan } \\
\text { dalam visum et } \\
\text { repertum }\end{array}$ & $\begin{array}{l}\text { lama kematian diperkirakan sekitar } 12 \\
\text { (dua belas) jam sejak saat pemeriksaan } \\
\text { (autopsi) dilaksanakan. Korban } \\
\text { mengalami luka lecet pada sekitar } \\
\text { tangan yang disebabkan kekerasan } \\
\text { tumpul. Korban meninggal oleh karena } \\
\text { mati lemas akibat adanya jeratan pada } \\
\text { daerah leher, yang menurut sifat dan } \\
\text { karakteristiknya bahwa jejas jeratan } \\
\text { terjadi akibat adanya kekuatan dari } \\
\text { luar (mati akibat jeratan/ strangulasi). } \\
\text { Adanya jejas jeratan lainnya pada } \\
\text { daerah leher yang sifat dan } \\
\text { karakteristiknya terjadi akibat adanya } \\
\text { kekuatan pengaruh berat badan korban } \\
\text { sendiri (jerat gantung/hanging) terjadi } \\
\text { setelah korban meninggal dunia. }\end{array}$ & $\begin{array}{l}\text { Hasil pemeriksaan dalam Visum et } \\
\text { Repertum No. } \\
\text { 812/329.17/RM/RSMW/2017 atas } \\
\text { mayat tidak disebutkan secara } \\
\text { lengkap; namun demikian, dikuatkan } \\
\text { keterangan dokter pembuat visum et } \\
\text { repertum di persidangan, bahwa luka } \\
\text { tersebut apabila mengenai organ } \\
\text { vital seperti kepala dan pembuluh } \\
\text { darah dapat berakibat fatal dan atau } \\
\text { bahkan kematian. }\end{array}$ \\
\hline
\end{tabular}

Sumber: Diolah penulis dari Putusan Pengadilan dan berbagai sumber.

Hakikat autopsi forensik dalam tindak pidana pembunuhan juga merupakan ukuran untuk menentukan kesalahan sebagai unsur dalam pertanggungjawaban pidana. Merujuk pada Tabel 1 mekanisme pemeriksaan luar dan dalam mayat dalam visum et repertum disebutkan secara lengkap apabila dilakukan autopsi forensik; namun demikian, terhadap mayat yang tidak diautopsi hanya diuraikan kondisi luka di luar tubuh. Dari autopsi forensik visum et repertum dalam Putusan No. 304/Pid.B/2016/PN Sim, dapat disimpulkan, 
bahwa "sifat dan karakteristik jejas jeratan terjadi akibat adanya kekuatan pengaruh berat badan korban sendiri (jerat gantung/hanging) terjadi setelah korban meninggal dunia"; sedangkan visum et repertum dalam Putusan No. 2/Pid.B/2018/PN Pso tidak menyimpulkan penyebab kematian korban, namun demikian keterangan dokter pembuat visum et repertum di persidangan menjelaskan, bahwa "luka pada tubuh korban apabila mengenai organ vital dapat berakibat fatal dan atau bahkan kematian". Keterangan dokter di persidangan dalam Putusan No. 2/Pid.B/2018/PN Pso yang menyatakan adanya perlukaan sebagai penyebab kematian didasarkan pada asumsi atau dugaan, yang tidak dapat menentukan hubungan kausal antara penyebab luka dengan akibat kematian korban secara pasti dan ilmiah.

Putusan No. 2/Pid.B/2018/PN Pso dapat disandingkan dengan kasus kematian Kepala Kesatuan Intelijen Kepolisian Resort Bogor ketika mengamankan aksi unjuk rasa mahasiswa 9 Mei 1998. Dugaan awal kematian dikarenakan pukulan batu oleh beberapa mahasiswa Universitas Juanda; kemudian korban dibawa ke Rumah Sakit (selanjutnya disebut RS) Ciawi dan selanjutnya dirujuk ke RS Palang Merah Bogor dan meninggal dunia satu jam kemudian; empat jam setelah kematian dilakukan autopsi forensik, dan visum et repertum menyimpulkan, bahwa penyakit jantung koroner adalah penyebab kematian korban. ${ }^{10}$ Penyakit jantung merupakan penyakit yang paling sering menyebabkan kematian,11 dan hanya dengan autopsi forensik itulah dapat disimpulkan penyebab kematian. Demikian pula, berdasarkan autopsi forensik dalam Putusan No. 304/Pid.B/2016/PN Sim dapat disimpulkan bahwa (jerat gantung/hanging) terjadi setelah korban meninggal dunia.

Kasus kematian anggota kepolisian Resort Bogor dan pembunuhan dalam Putusan No. 304/Pid.B/2016/PN Sim dapat dikaji dari teori kausalitas, khususnya teori individualisir yang dikemukakan oleh Brickmayer. Dalam hubungan

10 Y. A. Triana Ohoiwutun, Urgensi Bedah Mayat Forensik Dalam Pembuktian Tindak Pidana Pembunuhan Berencana Kajian Putusan Nomor 79/Pid.B/2012/PN.BGR, Jurnal Yudisial, Vol. 9 No. 1 2016, hlm. 84.

11 Jessyca Destiana Rorora, Djemi Tomuka, James Siwu, Temuan Otopsi Pada Kematian Mendadak Akibat Penyakit Jantung di BLU RSU Prof. Dr. R.D. Kandou Manado Periode 20072011, Jurnal e-Clinic (eCl), Vol. 2, No. 3 2014, hlm. 1. 
kausalitas Brickmayer ${ }^{12}$ mengemukakan bahwa, yang dilihat adalah sebab in concreto atau post factum, "meist wirksame bedingung, artinya dari berbagai macam syarat, dicari syarat manakah yang paling utama untuk menentukan akibat, perbuatan mana yang memberikan pengaruh paling besar terhadap timbulnya akibat".

Dengan autopsi forensik, kedua kasus kematian tersebut dapat disimpulkan penyebab utamanya. Kasus kematian anggota kepolisian Resort Bogor disebabkan sakit jantung koroner sehingga proses hukumnya dihentikan, sedangkan Putusan No. 304/Pid.B/2016/PN Sim proses hukumnya dilanjutkan karena ada peristiwa pembunuhan. Dengan demikian, dapat dikatakan bahwa hanya melalui pemeriksaan autopsi forensik suatu kebenaran materiil dapat terungkap dalam kasus kematian.

\section{Konsekuensi Yuridis Hubungan Antara Autopsi Forensik dengan Tindak Pidana Pembunuhan di dalam Pembuktian Perkara}

Penentuan penyebab pasti kematian seseorang hanya dapat disimpulkan dari pemeriksaan autopsi forensik. Penyebab pasti kematian seseorang dalam konteks hukum pidana bermuara pada penemuan kebenaran materiil sebagaimana dituju di dalam setiap pemeriksaan perkara pidana.

Hasil pemeriksaan autopsi forensik dalam kasus pembunuhan pada hakikatnya berhubungan erat dengan pertanggungjawaban pidana, dalam artian, untuk menentukan, apakah kematian korban berhubungan dengan perbuatan terdakwa? Sebagai delik materiil, adanya hubungan kausal antara perbuatan pelaku dengan hilangnya nyawa korban merupakan hubungan yang bersifat conditio sine qua non, dan jawaban atas penyebab pasti kematian korban hanya dapat dipenuhi melalui pemeriksaan autopsi forensik.

Putusan No. 304/Pid.B/2016/PN Sim hakim memutuskan terdakwa R alias D alias A telah terbukti secara sah dan meyakinkan bersalah melakukan tindak pidana turut serta melakukan pembunuhan berencana (Pasal 340 KUHP); sedangkan Putusan No. 2/Pid.B/2018/PN Pso memutuskan terdakwa K bin R

12 Eddy O.S. Hiariej, supra no. 8, hlm. 217. 
telah terbukti secara sah dan meyakinkan bersalah melakukan tindak pidana pembunuhan (Pasal 338 KUHP). Permasalahan penerapan Pasal 340 KUHP dan penerapan Pasal 338 KUHP dalam kedua putusan tersebut tidak dibahas dalam penulisan ini, karena fokus tulisan ini pada pemeriksaan autopsi forensik beserta implikasinya.

Terkait dengan pembuktian perkara Putusan No. 304/Pid.B/2016/PN Sim yang berbasis pada autopsi forensik dan perkara tanpa autopsi forensik dalam Putusan No. 2/Pid.B/2018/PN Pso dapat disandingkan dalam tabel 2:

\section{Tabel 2: Hubungan Antara Autopsi Forensik dengan Tindak Pidana Pembunuhan di dalam Pembuktian Perkara}

\begin{tabular}{|c|c|c|c|}
\hline No & Keterangan & Putusan No. 304/Pid.B/2016/PN Sim & Putusan No. 2/Pid.B/2018/PN Pso \\
\hline 1 & $\begin{array}{l}\text { Keterangan } \\
\text { ahli dokter } \\
\text { pembuat } \\
\text { visum et } \\
\text { repertum di } \\
\text { persidangan }\end{array}$ & $\begin{array}{l}\text { Berdasarkan pemeriksaan (autopsi) } \\
\text { disimpulkan bahwa: } \\
\text { - korban mengalami kematian } \\
\text { disebabkan adanya jeratan yang } \\
\text { dipengaruhi kekuatan dari luar } \\
\text { tubuhnya (strangulasi) sedangkan } \\
\text { adanya jejas jeratan yang } \\
\text { menggambarkan akibat pengaruh } \\
\text { dari berat tubuhnya sendiri } \\
\text { (hanging) terjadi setelah korban } \\
\text { meninggal dunia; } \\
\text { - sangatlah tidak mungkin bahwa } \\
\text { korban menggantungkan sendiri } \\
\text { dirinya setelah meninggal dunia. }\end{array}$ & $\begin{array}{l}\text { Hal-hal yang ditemukan dari pemeriksaan } \\
\text { luar adalah: } \\
\text { _ } \\
\text { terdapat luka lecet ukuran } 3 x 2 \text { (tiga } \\
\text { kali dua) sentimeter di bagian sudut } \\
\text { mata sebelah kanan; } \\
\text { - } \text { terdapat luka yang sudah terjahit } \\
\text { dengan panjang kurang lebih } 2 \text { (dua) } \\
\text { sentimeter disertai bekuan darah di } \\
\text { sekitar luka, dan luka tersebut } \\
\text { terdapat pada bagian tubuh di } \\
\text { belakang telinga sebelah kiri; } \\
\text { - luka yang sudah terjahit dengan } \\
\text { ukuran panjang sekitar } 2 \text { (dua) } \\
\text { sentimeter pada garis tengah } \\
\text { punggung dan tidak ditemukan } \\
\text { bekuan darah di sekitar luka; } \\
\text { - terdapat pengeluaran cairan dari } \\
\text { mulut dan hidung saat tubuh } \\
\text { terperiksa dibalik, dan cairan tersebut } \\
\text { berbusa dengan warna kemerahan } \\
\text { yang keluar dari mulut dan hidung; } \\
\text { - Ada jenis luka yang bisa } \\
\text { menyebabkan kematian dan ada juga } \\
\text { luka yang tidak menyebabkan } \\
\text { kematian; } \\
\text { untuk kondisi korban yang pada saat } \\
\text { diterima dalam kondisi korban telah } \\
\text { meninggal dunia, pada tubuh korban } \\
\text { hanya dilakukan pemeriksaan luar } \\
\text { dan tidak melakukan pemeriksaan } \\
\text { dalam; } \\
\text { luka yang terdapat di bagian belakang } \\
\text { telinga sebelah kiri atau di bagian } \\
\text { punggung bawah serta luka pada } \\
\text { bagian mata kanan tidak dapat ahli } \\
\text { simpulkan apakah dapat } \\
\text { menyebabkan kematian atau tidak. }\end{array}$ \\
\hline
\end{tabular}




\begin{tabular}{|c|c|c|c|}
\hline 2 & $\begin{array}{l}\text { Ratio } \\
\text { decidendi } \\
\text { hakim atas } \\
\text { alat bukti } \\
\text { visum et } \\
\text { repertum dan } \\
\text { keterangan } \\
\text { ahli }\end{array}$ & $\begin{array}{l}\text { Berdasarkan bukti surat berupa Visum } \\
\text { et Repertum No. 4939/IV/UPM/V/2016 } \\
\text { dengan kesimpulan: } \\
\text { - dari hasil pemeriksaan luar dan } \\
\text { dalam perkiraan lama kematian } \\
\text { sekitar } 12 \text { jam sejak saat } \\
\text { pemeriksaan (autopsi) dan korban } \\
\text { mengalami luka lecet pada sekitar } \\
\text { tangan yang disebabkan kekerasan } \\
\text { benda tumpul; } \\
\text { - Korban meninggal dunia oleh karena } \\
\text { mati lemas akibat adanya jeratan } \\
\text { pada leher yang menurut sifat dan } \\
\text { karakteristiknya bahwa jejas jeratan } \\
\text { terjadi akibat adanya kekuatan dari } \\
\text { luar (mati akibat } \\
\text { jeratan/strangulasi); } \\
\text { - Adanya jejas jeratan lainnya pada } \\
\text { daerah leher yang sifat dan } \\
\text { karakteristiknya terjadi akibat } \\
\text { adanya kekuatan pengaruh berat } \\
\text { badan korban sendiri (jerat } \\
\text { gantung/hanging) terjadi setelah } \\
\text { korban meninggal dunia. }\end{array}$ & $\begin{array}{l}\text { Berdasarkan bukti surat berupa Visum et } \\
\text { repertum No. 812/329-17/RM/RSMW/ } \\
2017 \text { dengan hasil pemeriksaan: } \\
\text { - } \text { pada tubuh korban terdapat luka lecet } \\
\text { ukuran } 3 \times 2 \mathrm{~cm} \text { di sudut mata kanan; } \\
\text { - } \quad \text { terdapat luka terjahit ukuran panjang } \\
2 \text { cm setelah ditautkan, disertai } \\
\text { bekuan darah berwarna merah } \\
\text { kehitaman di sekitarnya; } \\
\text { - } \quad \text { pada punggung ditemukan luka } \\
\text { terjahit dengan garis tengah punggung } \\
\quad \text { dengan jarak } 44 \text { cm dari leher, ukuran } \\
\text { panjang luka } 2 \text { cm tidak terdapat } \\
\text { bekuan darah di sekitarnya. } \\
\\
\text { catatan: dalam putusan perkara tidak } \\
\text { menyebutkan kesimpulan dari Visum et } \\
\text { Repertum No. } 812 / 329- \\
\text { 17/RM/RSMW/2017 }\end{array}$ \\
\hline 3 & $\begin{array}{l}\text { Keyakinan } \\
\text { hakim dalam } \\
\text { memutus } \\
\text { perkara }\end{array}$ & $\begin{array}{l}\text { - Berdasarkan hasil autopsi forensik } \\
\text { yang dilakukan oleh dokter: bahwa } \\
\text { korban mati gantung (hanging) } \\
\text { hanya pada mekanisme kematian } \\
\text { dan sebab kematian saja; sedangkan } \\
\text { cara kematian, bunuh diri, } \\
\text { pembunuhan atau kecelakaan maka } \\
\text { dokter hanya dapat memberikan } \\
\text { petunjuk berdasarkan hasil } \\
\text { pemeriksaan atas mayat; } \\
\text { - Dokter ahli berdasarkan autopsi } \\
\text { forensik menyimpulkan, kematian } \\
\text { korban disebabkan karena jeratan } \\
\text { yang menggambarkan akibat } \\
\text { pengaruh berat tubuhnya sendiri } \\
\text { (hanging) terjadi setelah korban } \\
\text { meninggal dunia; oleh karena itu } \\
\text { sangatlah tidak mungkin bahwa } \\
\text { korban menggantungkan sendiri } \\
\text { dirinya setelah meninggal dunia. } \\
\text { - Dalam hubungan dengan jejas jerat } \\
\text { akibat mati jerat (strangulasi) maka } \\
\text { kecenderungan bahwa jeratan } \\
\text { tersebut terjadi (didapat) bukan oleh } \\
\text { korban sendiri (bunuh diri); } \\
\text { - pada jejas jerat akibat kekuatan dari } \\
\text { luar ditemukan beberapa jejas } \\
\text { lainnya yang dapat diartikan sebagai } \\
\text { kemungkinan bentuk perlawanan } \\
\text { dari korban, yaitu adanya memar } \\
\text { disertai luka lecet pada daerah dagu } \\
\text { serta tangan korban. }\end{array}$ & 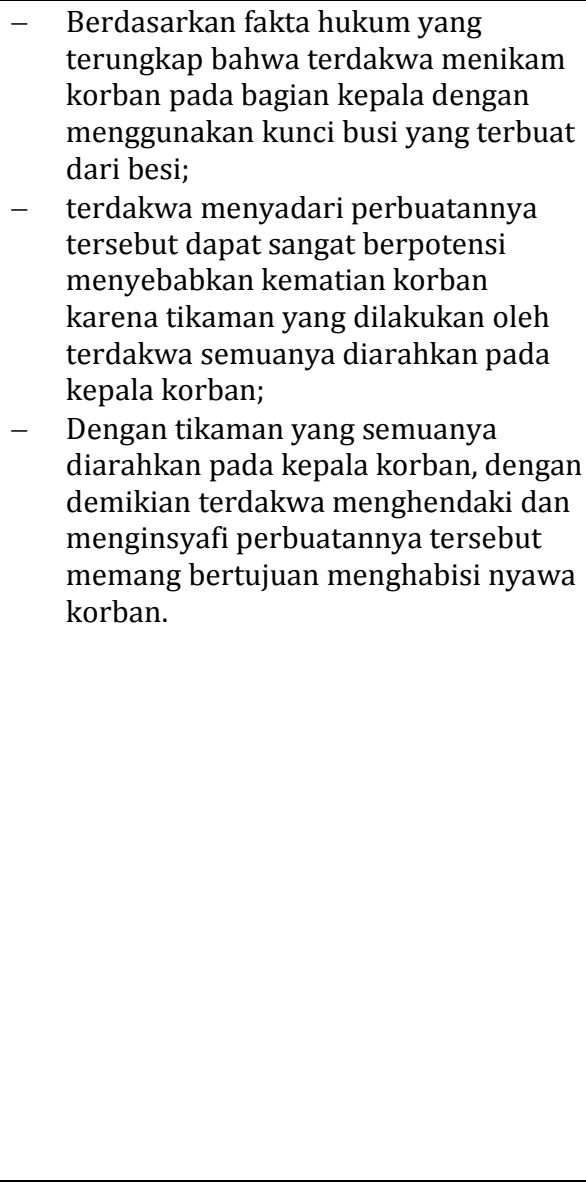 \\
\hline
\end{tabular}

Sumber: Diolah penulis dari Putusan Pengadilan dan berbagai sumber. 
Putusan No. 304/Pid.B/2016/PN Sim dan Putusan No. 2/Pid.B/2018/PN Pso turut melibatkan dokter dalam menentukan penyebab kematian korban. Penerbitan visum et repertum atas kedua putusan tersebut mengindikasikan, bahwa penyebab kematian korban dituangkan di dalamnya. Visum et repertum merupakan alat bukti yang penting dalam setiap kasus kejahatan terhadap tubuh dan nyawa. Posisi visum et repertum sebagai pengganti barang bukti tubuh manusia untuk dihadirkan dalam pembuktian perkara pada kasus kematian, seharusnya melalui pemeriksaan autopsi forensik agar memiliki nilai pembuktian yang dapat dipertanggungjawabkan secara ilmiah, karena tanpa autopsi forensik tidak dapat ditentukan penyebab pasti kematian korban.

Dalam Putusan No. 304/Pid.B/2016/PN Sim dan Putusan No. 2/Pid.B/2018/PN Pso, di samping menjadikan visum et repertum sebagai alat bukti surat, juga menghadirkan dokter pembuat visum et repertum di persidangan. Kehadiran dokter di persidangan sebagai ahli bermanfaat untuk menguatkan keyakinan hakim di dalam memutus perkara.

Putusan No. 304/Pid.B/2016/PN Sim dalam Visum et Repertum No. 4939/IV/UPM/2016 berbasis pada hasil pemeriksaan luar mayat dan autopsi forensik, dalam kesimpulannya jelas menerangkan penyebab "korban meninggal oleh karena mati lemas akibat adanya jeratan pada daerah leher, yang menurut sifat dan karakteristiknya bahwa jejas jeratan terjadi akibat adanya kekuatan dari luar (mati akibat jeratan/strangulasi); adanya jejas jeratan lainnya pada daerah leher yang sifat dan karakteristiknya terjadi akibat adanya kekuatan pengaruh berat badan korban sendiri (jerat gantung/hanging) terjadi setelah korban meninggal dunia".

Hasil pemeriksaan dokter pembuat visum et repertum atas mayat dalam Putusan No. 304/Pid.B/2016/PN Sim, baik pemeriksaan luar maupun autopsi forensik diperkuat dengan keterangan dokter yang dihadirkan di persidangan. Keterangan ahli dokter pembuat visum et repertum di persidangan yang berbasis pada pemeriksaan autopsi forensik menyimpulkan bahwa: korban mengalami kematian disebabkan adanya jeratan yang dipengaruhi kekuatan dari luar tubuhnya (strangulasi); sedangkan adanya jejas jeratan yang menggambarkan 
akibat pengaruh dari berat tubuhnya sendiri (hanging) terjadi setelah korban meninggal dunia, dan sangatlah tidak mungkin bahwa korban menggantungkan sendiri dirinya setelah meninggal dunia.

Keterangan dokter di persidangan Putusan No. 304/Pid.B/2016/PN Sim menjadi pertimbangan hakim dalam memutus perkara, yang point pentingnya adalah: berdasarkan autopsi forensik menyimpulkan, kematian korban disebabkan karena jeratan yang menggambarkan akibat pengaruh berat tubuhnya sendiri (hanging) terjadi setelah korban meninggal dunia, oleh karena itu sangatlah tidak mungkin bahwa korban menggantungkan sendiri dirinya setelah meninggal dunia. Dengan demikian, eksistensi autopsi forensik dalam Putusan No. 304/Pid.B/2016/PN Sim secara jelas menerangkan penyebab kematian korban dan hubungan kausal antara penyebab dengan akibat yang ditimbulkannya. Secara teknis yuridis, autopsi forensik menjelaskan mengenai sebab kematian dan akibat tertentu secara medis, namun demikian tugas hakim yang menilai dan menentukan ada atau tidaknya hubungan kausal antara hasil pemeriksaan kedokteran forensik dengan fakta peristiwa pidana yang sedang diperiksanya.

Dalam Putusan No. 2/Pid.B/2018/PN Pso ada 2 (dua) jenis visum et repertum sebagai alat bukti surat, yaitu Visum et Repertum No.: 445.1/275/UPTD.PKM-KLRG/2017 dan Visum et Repertum No. 812/329.17/RM/RSMW/2017. Visum et Repertum No.: 445.1/275/UPTD.PKMKLRG/2017 di dalam ilmu kedokteran forensik lazim disebut visum et repertum sementara, yang dibuat pada saat korban dalam keadaan hidup dan korban diterima ke dalam fasilitas sarana pelayanan kesehatan, dalam hal ini dibuat oleh Puskesmas Desa Kaleroang Kecamatan Bungku Selatan Kabupaten Morowali tanggal 17 September 2017; dan Visum et Repertum No. 812/329.17/RM/RSMW/2017 atas mayat sebagai visum et repertum lanjutan yang dibuat oleh RSUD Morowali tanggal 20 September 2020.

Kesimpulan dalam Visum et Repertum No.: 445.1/275/UPTD.PKMKLRG/2017 menyebutkan: dari hasil pemeriksaan didapatkan satu buah luka lecet di bawah mata kanan yang diduga diakibatkan oleh persentuhan benda tumpul, dan didapatkan satu buah luka tusuk di belakang telinga kiri, satu buah luka tusuk 
di punggung belakang bagian bawah yang diduga persentuhan benda tajam; luka tersebut menimbulkan halangan dalam melakukan kegiatan/pekerjaan seharihari dan membutuhkan penanganan medis lebih lanjut. Visum et Repertum No. 812/329.17/RM/RSMW/2017 sebagai visum et repertum lanjutan, dengan dikuatkan oleh keterangan saksi dokter yang melakukan pemeriksaan mayat korban, bahwa:

"luka tersebut apabila mengenai organ vital seperti kepala dan pembuluh darah dapat berakibat fatal dan atau bahkan kematian, dan jika dilihat dari posisi luka terdapat pada tempat organ vital, maka untuk dapat memastikan terjadinya dampak pada organ vital tersebut harus dilakukan pemeriksaan dalam atau autopsi".

Dalam Putusan No. 2/Pid.B/2018/PN Pso, berdasarkan keterangan ahli dokter pembuat visum et repertum di persidangan hal-hal penting yang ditemukan dari pemeriksaan luar antara lain adalah: ada jenis luka yang bisa menyebabkan kematian dan ada juga luka yang tidak menyebabkan kematian; kondisi korban yang pada saat diterima telah meninggal dunia, pada tubuh mayat hanya dilakukan pemeriksaan luar dan tidak dilakukan pemeriksaan dalam; luka yang terdapat di bagian belakang telinga sebelah kiri atau di bagian punggung bawah serta luka pada bagian mata kanan tidak dapat ahli simpulkan apakah dapat menyebabkan kematian atau tidak.

Keterangan ahli bersifat terbatas pada hasil kecermatan dan ketelitian dokter ketika melakukan pemeriksaan mayat, dan visum et repertum pada hakikatnya hanyalah menguraikan suatu kondisi luka dan akibat perlukaan. Visum et repertum dan keterangan ahli tidak dapat membuktikan suatu kejahatan dan siapa pelakunya, karena hal itu merupakan tugas hakim untuk menilai adanya suatu kejahatan dan menilai berdasarkan fakta yang terungkap di persidangan apakah benar si terdakwa pelakunya.

Ratio decidendi hakim berdasarkan Visum et Repertum No. 812/32917/RM/RSMW/2017 dengan hasil pemeriksaan: pada tubuh korban terdapat luka lecet ukuran $3 \times 2 \mathrm{~cm}$ di sudut mata kanan; terdapat luka terjahit ukuran panjang 2 cm setelah ditautkan, disertai bekuan darah berwarna merah kehitaman di sekitarnya. Visum et Repertum No. 812/329.17/RM/RSMW/2017 dalam Putusan 
No. 2/Pid.B/2018/PN Pso tidak menerangkan secara terperinci hasil dari pemeriksaan dan kesimpulan dari adanya perlukaan dengan segala akibatnya; namun demikian, keyakinan hakim dalam memutus perkara berdasarkan fakta yang terungkap di persidangan, bahwa tikaman terdakwa diarahkan pada bagian kepala korban dengan menggunakan kunci busi yang terbuat dari besi yang sangat berpotensi menyebabkan kematian; dan dengan tikaman yang semuanya diarahkan pada kepala korban, dengan demikian terdakwa menghendaki dan menginsyafi perbuatannya memang bertujuan menghilangkan nyawa korban.

Peniadaan autopsi forensik atas mayat korban, dan "tikaman kunci busi yang terbuat dari besi yang sangat berpotensi menyebabkan kematian" merupakan kesimpulan yang diambil berdasarkan keterangan saksi dan keterangan terdakwa serta fakta yang terungkap di persidangan; bahkan keterangan ahli dokter pembuat visum et repertum-pun tidak dapat menyimpulkan bahwa luka-luka yang terdapat pada beberapa bagian tubuh korban sebagai penyebab kematian. Dengan demikian, kesimpulan penyebab pasti kematian korban dalam Putusan No. 2/Pid.B/2018/PN Pso tidak secara an sich berdasarkan pemeriksaan mayat, karena tidak dilakukannya autopsi forensik sehingga tidak dapat dipastikan adanya hubungan kausal antara tikaman kunci busi yang mengakibatkan kematian korban.

Putusan No. 304/Pid.B/2016/PN Sim dan Putusan No. 2/Pid.B/2018/PN Pso, menjadikan visum et repertum sebagai alat bukti surat. Apabila merujuk KUHAP Pasal 187 huruf c, kualifikasi alat bukti surat adalah surat keterangan dari seorang ahli yang memuat pendapat berdasarkan keahliannya mengenai sesuatu hal atau sesuatu keadaan yang diminta secara resmi dari padanya; sedangkan menurut Eddy O.S. Hiariej, ${ }^{13}$ visum et repertum sebagai alat bukti, meskipun isinya berupa keterangan ahli yang diberikan di bawah sumpah dan di luar sidang pengadilan, namun kualifikasinya sebagai alat bukti surat dan bukan alat bukti keterangan ahli.

13 Eddy O.S. Hiariej, Teori \& Hukum Pembuktian, Erlangga, Jakarta, 2012, hlm. 107. 
Sejalan dengan pendapat Hiariej, bahwa sebagai alat bukti, posisi visum et repertum merupakan alat bukti surat; namun demikian KUHAP Pasal 179 ayat (1), menentukan bahwa setiap orang yang diminta pendapatnya sebagai ahli kedokteran kehakiman atau dokter atau ahli lainnya wajib memberikan keterangan ahli demi keadilan. Berdasarkan KUHAP Pasal 179 ayat (1), dokter pembuat visum et repertum yang memberikan keterangannya di persidangan dalam Putusan No. 304/Pid.B/2016/PN Sim dan Putusan No. 2/Pid.B/2018/PN Pso keterangannya dikualifikasikan sebagai alat bukti keterangan ahli.

Selanjutnya, posisi keterangan dokter pembuat visum et repertum yang dihadirkan di dalam persidangan dinilai oleh hakim sebagai alat bukti keterangan ahli. Hal ini tidaklah keliru apabila merujuk pada Pasal 186 KUHAP, bahwa keterangan ahli ialah apa yang seorang ahli nyatakan di sidang pengadilan; di samping itu, jumlah ahli yang dapat dihadirkan di persidangan secara kuantitatif tidak ditentukan di dalam KUHAP, namun secara kualitatif keterangan ahli disyaratkan diberikan oleh orang yang memiliki keahlian khusus yang diperlukan untuk membuat terang suatu perkara pidana atau dapat dikatakan, bahwa kualitas ahli sesuai dengan kompetensi atau profesinya di bidang tertentu yang ditujukan untuk membuat terang suatu peristiwa pidana.

Putusan No. 304/Pid.B/2016/PN Sim dan Putusan No. 2/Pid.B/2018/PN Pso "hanya" menghadirkan seorang dokter sebagai ahli. Keterangan seorang ahli tersebut kebenarannya tidak disangkal baik oleh terdakwa, maupun penasihat hukumnya. Secara substansi keterangan ahli juga telah diyakini oleh hakim, sehingga hakim memandang telah cukup dalam pembuktian perkara. Keterangan satu orang ahli saja sudah cukup untuk satu pokok masalah, ${ }^{14}$ menurut hemat penulis, kehadiran ahli dokter pembuat visum et repertum diperlukan sebagai sarana bagi hakim dalam mengkonfirmasi hasil pemeriksaan yang telah dituliskan di dalam visum et repertum.

14 Avarakha Denny Prasetya dan Kristiyadi, Keterangan Ahli sebagai Alat Bukti dan Pertimbangan Hakim Tidak Menjatuhkan Pidana Penjara Dalam Memutus Persidangan Perkara di Bidang Perikanan, Jurnal Verstek, Vol. 8, No. 1 2020, hlm. 43. 
Kehadiran ahli dokter pembuat visum et repertum dalam persidangan Putusan No. 304/Pid.B/2016/PN Sim dan Putusan No. 2/Pid.B/2018/PN Pso untuk menjelaskan segala sesuatu terkait dengan pemeriksaan mayat yang telah dilakukannya. Hal ini sejalan dengan ketentuan KUHAP Pasal 180 ayat (1), bahwa dalam hal diperlukan untuk menjernihkan duduknya persoalan yang timbul di sidang pengadilan, hakim ketua sidang dapat meminta keterangan ahli dan dapat pula minta agar diajukan bahan baru oleh yang berkepentingan. Merujuk pada KUHAP Pasal 180 ayat (1), kepentingan menghadirkan ahli dan pilihan mengenai ahli yang dihadirkan di persidangan merupakan otoritas sepenuhnya hakim di dalam memeriksa setiap perkara pidana.

Karakteristik ahli dalam memberikan keterangan di persidangan berlandaskan pada (ilmu) pengetahuan yang sebaik-baiknya, atau menurut Arfan Faiz Muhlizi, ${ }^{15}$ ahli memberikan keterangannya berdasarkan keahlian khusus yang dimilikinya. Bertolak dari syarat keahlian khusus bagi seorang ahli, menurut penulis konsekuensinya, ahli berhak untuk menolak atau menjelaskan segala sesuatu di luar keahliannya atau pengetahuannya.

Posisi ahli dalam mekanisme pemeriksaan perkara pidana berbeda dengan saksi yang memberikan keterangan yang sebenar-benarnya berdasarkan apa yang dilihat, didengar atau dialaminya (lazim disebut saksi fakta). Konsekuensi dari perbedaan kualitas antara ahli dengan saksi fakta antara lain dalam memberikan keterangan, ahli dapat memberikan kesimpulan terkait dengan substansi keterangannya; sedangkan saksi fakta tidak dapat menyimpulkan berdasarkan hal-hal yang dilihat, didengar atau dialaminya.

Merujuk pada Putusan No. 304/Pid.B/2016/PN Sim yang berbasis pada pemeriksaan autopsi forensik dalam rangka pembuatan visum et repertum, ahli dapat menyimpulkan yang pada intinya bahwa kematian korban disebabkan jeratan yang dipengaruhi oleh kekuatan dari luar tubuhnya (strangulasi) yang terjadi setelah korban meninggal dunia, dan tidaklah mungkin korban

15 Arfan Faiz Muhlizi, Refleksi atas Peran Saksi Ahli di Pengadilan dan Tanggung Jawab Intelektual, Jurnal Rechts Vinding Online, 1, hlm. 2 https://rechtsvinding.bphn.go.id/jurnal_online/REFLEKSI\%20ATAS\%20PERAN\%20SAKSI\%2 0AHLI\%20DI\%20 PENGADILAN.pdf. 
menggantungkan sendiri dirinya setelah meninggal dunia; sedangkan Putusan No. 2/Pid.B/2018/PN Pso berbasis pada pemeriksaan luar mayat, ahli dalam keterangannya di persidangan menyatakan, bahwa luka yang terdapat di bagian belakang telinga sebelah kiri atau di bagian punggung bawah serta luka pada bagian mata kanan tidak dapat ahli simpulkan apakah dapat menyebabkan kematian atau tidak. Dengan demikian, meskipun dokter tidak dapat menyimpulkan penyebab pasti kematian korban dalam Putusan No. 2/Pid.B/2018/PN Pso, namun kesimpulan dokter diberikan berbasis pada perlukaan (trauma) yang terdapat pada luar tubuh korban. Secara teknis yuridis, meskipun dokter tidak dapat menentukan penyebab pasti kematian korban dalam Putusan No. 2/Pid.B/2018/PN Pso, namun demikian, hakim yakin bahwa kematian korban disebabkan karena perbuatan terdakwa yang menikam korban pada bagian kepala menggunakan kunci busi yang terbuat dari besi yang sangat berpotensi menyebabkan kematian korban. Fakta hukum mengenai perbuatan terdakwa yang terungkap di persidangan inilah yang menjadikan hakim yakin atas kesalahan terdakwa.

KUHAP menentukan berlakunya asas unus testis nullus testis, yaitu seorang saksi bukan saksi dengan pengecualiannya terkait dengan jumlah minimal keterangan saksi; tidak demikian halnya dengan keterangan ahli, artinya tidak ada pembatasan mengenai jumlah ahli yang dapat dihadirkan di persidangan. Keterangan seorang ahlipun telah cukup apabila tidak ada keberatan yang beralasan dari penuntut umum, terdakwa atau penasihat hukumnya. KUHAP Pasal 180 ayat (2) menentukan, dalam hal timbul keberatan yang beralasan dari terdakwa atau penasihat hukum terhadap hasil keterangan ahli sebagaimana dimaksud ayat (1) hakim memerintahkan agar hal itu dilakukan penelitian ulang.

Bertolak pada KUHAP Pasal 180 ayat (2), keberadaan ahli dalam setiap pemeriksaan perkara pidana bergantung pada dinamika yang terjadi di pengadilan, artinya untuk menghadirkan ahli di persidangan bergantung sepenuhnya pada penilaian hakim. Dalam proses persidangan Putusan No. 304/Pid.B/2016/PN Sim maupun Putusan No. 2/Pid.B/2018/PN Pso, sebenarnya hakim berwenang sepenuhnya untuk memeriksa atau memilih dokter lain (bukan 
dokter pembuat visum et repertum) dalam pemeriksaan di pengadilan; namun demikian, tidak dihadirkannya dokter lain merupakan otoritas penuh bagi hakim dalam setiap pemeriksaan perkara pidana.

Optimalisasi pengungkapan perkara kejahatan terhadap nyawa atau tubuh dapat dilakukan melalui pemeriksaan kedokteran forensik untuk tujuan penemuan kebenaran materiil. Tanpa autopsi forensik sebagaimana kasus Putusan No. 2/Pid.B/2018/PN Pso tidak dapat dipastikan adanya hubungan kausal antara perbuatan terdakwa dengan akibat kematian korban; namun demikian, meskipun tanpa autopsi forensik tidak menjadikan terdakwa bebas berdasarkan alat bukti dan fakta-fakta yang terungkap di persidangan. Memang, hakim memiliki kekuasaan absolut dalam memeriksa dan memutus perkara, meskipun terbatas dan dibatasi oleh KUHAP Pasal 183 dan Pasal 184, namun sepanjang ratio decidendi hakim bersifat logis, rasional dan ilmiah yang melandasi pertimbangannya, maka putusan hakim dapat diterima oleh semua pihak, khususnya para pencari keadilan.

\section{Penutup}

Tindak pidana pembunuhan diformulasikan sebagai delik materiil, dan akibat hilangnya nyawa merupakan unsur delik; oleh karena itu, hubungan kausal antara sebab perbuatan terdakwa yang berakibat kematian korban harus dapat dibuktikan. Hanya melalui pemeriksaan autopsi forensik, penyebab pasti kematian korban dapat disimpulkan dalam visum et repertum. Urgensi autopsi forensik, antara lain untuk mengungkap misteri kematian, menentukan ada atau tidaknya peristiwa pembunuhan, di samping menentukan adanya kesalahan dan pertanggungjawaban pidana.

Melalui pemeriksaan autopsi forensik, dokter pembuat visum et repertum dapat menyimpulkan secara lengkap dan jelas mengenai penyebab kematian korban pembunuhan. Pertimbangan hakim dalam kasus pembunuhan yang berbasis pada autopsi forensik berdasarkan visum et repertum dan keterangan dokter di persidangan mengindikasikan bahwa ratio decidendi hakim dapat dipertanggungjawabkan secara ilmiah kebenaran materiilnya; namun demikian, 
tanpa autopsi forensik ratio decidendi hakim di dalam memutus perkara lebih didasarkan pada kesalahan terdakwa dan fakta perbuatan terdakwa yang terbukti dan terungkap di persidangan.

Urgensi autopsi forensik dalam kasus pembunuhan secara tidak langsung dapat dihubungkan dengan nilai dasar hukum, yaitu kepastian, kemanfaatan dan keadilan, baik bagi korban dan keluarganya, masyarakat maupun terdakwa. Oleh karena itu, dengan atau tanpa persetujuan keluarga korban, autopsi forensik seyogianya dapat dilaksanakan dalam setiap kasus kematian yang diduga tidak wajar. Dengan demikian, secara tidak langsung autopsi forensik juga berperan dalam memenuhi nilai dasar hukum, yaitu kepastian, kemanfaatan dan keadilan.

\section{Daftar Pustaka}

\section{Buku:}

Departemen Pendidikan Nasional, Kamus Besar Bahasa Indonesia Edisi Keempat, Gramedia Pustaka Utama, Jakarta, 2015.

Eddy O.S. Hiariej, Teori \& Hukum Pembuktian, Erlangga, Jakarta, 2012.

Eddy O.S. Hiariej, Prinsip-prinsip Hukum Pidana, Cahaya Atma Pustaka, Yogyakarta, 2016.

M. Marwan dan Jimmy P, Kamus Hukum Dictionary of Law Complete Edition, Reality Publisher, Surabaya, 2009.

Peter Mahmud Marzuki, Penelitian Hukum Normatif, Kencana, Jakarta, 2011.

Wirjono Prodjodikoro, Tindak-Tindak Pidana Tertentu di Indonesia, Refika Aditama, Bandung, 2012.

Y.A. Triana Ohoiwutun, Ilmu kedokteran Forensik (Interaksi dan Dependensi Hukum pada Ilmu Kedokteran), Pohon Cahaya, Yogyakarta, 2016.

\section{Jurnal}

Arfan Faiz Muhlizi, Refleksi atas Peran Saksi Ahli di Pengadilan dan Tanggung Jawab Intelektual, Jurnal Rechts Vinding Online, https://rechtsvinding.bphn.go.id/jurnalonline/REFLEKSI\%20ATAS\%20PE RAN\%20SAKSI\%20AHLI\%20DI\%20 PENGADILAN.pdf. 
Avarakha Denny Prasetya dan Kristiyadi, Keterangan Ahli sebagai Alat Bukti dan Pertimbangan Hakim Tidak Menjatuhkan Pidana Penjara Dalam Memutus Persidangan Perkara di Bidang Perikanan, Jurnal Verstek Vol. 8 No. 1.

Jessyca Destiana Rorora, Djemi Tomuka, James Siwu, Temuan Otopsi Pada Kematian Mendadak Akibat Penyakit Jantung di BLU RSU Prof. Dr. R.D. Kandou Manado Periode 2007-2011, Jurnal e-Clinic (eCl) Vol. 2 No. 3, November 2014.

Kastubi, Fungsi Bedah Mayat Forensik (Autopsi) Untuk Mencari Kebenaran Materiil Dalam Suatu Tindak Pidana, Jurnal Spektrum Hukum Vol. 13 No. 1, April 2016.

Marhcel M. Maramis, Tinjauan Yuridis Terhadap Otopsi Medikolegal Dalam Pemeriksaan Mengenai Sebab-sebab Kematian, Jurnal Hukum Unsrat Vol. 21 No. 5 Januari 2016.

Putu Pradnyasanti Laksmi, IB Putu Alit, Henky, Deskripsi Faktor-Faktor Yang Memengaruhi Penolakan Otopsi Pada Kasus Kematian Yang Diduga Tidak Wajar, Jurnal Medika Udayana Vol. 9 No. 7 Juli 2020.

Y.A. Triana Ohoiwutun, Urgensi Bedah Mayat Forensik Dalam Pembuktian Tindak Pidana Pembunuhan Berencana Kajian Putusan Nomor 79/Pid.B/2012/PN.BGR, Jurnal Yudisial Vol. 9 No. 1 April 2016.

\section{Peraturan Perundangan dan Putusan Pengadilan}

Undang-undang RI No. 8 Tahun 1981 tentang Kitab Undang-undang Hukum Acara Pidana, L.N. R.I. 1981 No. 76, TLN 3258.

Instruksi Kapolri No. Pol.: Ins/E/20/IX/75 tanggal 19 September 1975 tentang Tata Cara Permohonan/Pencabutan Visum et Repertum.

Putusan PN Simalungun No. 304/Pid.B/2016/PN Sim.

Putusan PN Poso No. 2/Pid.B/2018/PN Pso. 